(C)2019. This manuscript version is made available under the CC-BY-NC 4.0

license http://creativecommons.org/licenses/by-nc/4.0/

\title{
$\underline{\text { Student residences: Time for a partnership approach? }}$
}

\author{
Laura McCann'1, Norman Hutchison"1, Alastair Adair ${ }^{2}$ \\ ${ }^{1}$ University of Aberdeen Business School, Aberdeen, Scotland. UK \\ ${ }^{2}$ Ulster University, Belfast, Northern Ireland. UK
}

\begin{abstract}
Purpose

Recent years have witnessed significant increases in the number of undergraduate students entering UK higher education. This increase is a result of the removal of the sector-wide cap on student numbers in England and Wales, along with growth in overseas students attracted by the reputation of UK universities and the weakening of the value of Sterling. Adopting a corporate real estate perspective, the aim of this paper is to understand how the UK student residence market is structured and financed, and to identify the motivations that are driving the strategies adopted by the universities, private sector providers and investors in this market. In doing so, this research seeks to test the appropriateness of the Gibler and Lindholm (2012) model of corporate real estate strategy in the UK higher education sector.
\end{abstract}

\section{Design/methodology/approach}

Data was gathered from a survey of UK university secretaries, combined with interviews of private sector providers, bank lenders and the analysis of secondary data on investment flows into Purpose Built Residential Accommodation (PBSA).

\section{Findings}

UK university real estate strategy is mainly one of outsourcing student accommodation to reduce costs as well as employing modern purpose-built student housing as a marketing tool and brand enhancer. This strategy is also used as a risk mitigatory tool enabling universities to adjust to changing student demands. Revisions to the Gibler and Lindholm (2012) model are proposed to reflect the reality of the real estate strategy adopted by the universities. Private sector providers view the sector favourably and are set to be the main providers of new supply over the next decade, entering into strong partnerships with the universities. While there is evidence of some oversupply of bed spaces in certain cities, well located developments are viewed as an attractive lending opportunity. Since 2013 there has been significant growth in institutional investment into UK student accommodation, albeit sentiment is currently tempered by political uncertainty.

\section{Practical Implications}

The role of PBSA designed to meet modern student requirements is playing a critical role not only in attracting, recruiting and retaining students, but also enhancing the overall higher education experience promoting student welfare and wellbeing. 


\section{Originality/Value}

The corporate real estate strategy adopted by the UK higher education sector is an under researched area. This paper focuses on the strategy surrounding student accommodation provision and reports on the findings of an extensive survey of the key players in this sector. The results are of value to all stakeholders including government and regulators, at a time when higher education is facing substantial challenges. The evidence of a growing partnership between universities and the private sector is viewed as a logical solution, both for the present and the foreseeable future.

Key words: Student accommodation; real estate strategy; outsourcing; university funding; Higher Education sector; private sector providers 


\section{Introduction}

UK universities have recruited an increasing number of students in recent years. Between 2010 and 2016, Higher Education Policy Institute (HEPI) data indicated there had been a 5.5 percent increase in undergraduate numbers driven primarily by the removal of the cap on student numbers introduced in 2015/2016 and partly down to demographical factors. The recruitment of non-UK students has similarly increased not only due to the removal of the student cap, but because of the weak value of Sterling in recent years which has made study in the UK attractive to non-UK nationals, and at present almost $25 \%$ of students studying at UK universities come from a non-UK background. Combined, the increase in students studying away from home has triggered an increase in the number of students requiring accommodation during their studies with $27.49 \%$ of students staying in purpose-built student accommodation (PBSA) in 2017/18. While across the UK there is presently a dip in the number of 18 year olds in the period to 2022 , the trend of increasing student numbers is expected to continue over the next decade with the HEPI (2018) predicting growth in the region of 300,000 to 2030 prompting the need for investment in student accommodation to house the increasing number of students.

Whilst there has been an increase in students requiring accommodation in recent years and an increase expected in the future, this coincides with a time of reduced government funding in universities and uncertainty regarding tuition fee income for English universities following the recommendation in 2019 by the Augar Review ${ }^{1}$ to cut tuition fees for undergraduate students from $£ 9,250$ to $£ 7,500$ per annum, with overall university sector income protected by an increased government contribution to teaching costs. While it may be argued that rather than invest in student accommodation directly, universities may wish to divest their accommodation provision to a third party to allow them to concentrate on investing in core educational activities, there is a strong counter argument that the provision of enhanced student life/wellbeing concept facilities, including attractive and affordable student accommodation is a major recruitment factor for universities. Indeed, according to the National Union of Students (NUS, 2018), almost half of students stated that their choice of university was influenced by the accommodation offered. Moreover, the 2018-19 Knight Frank student accommodation survey of students indicated that $70 \%$ of first year students opted to stay in either university or private sector run PBSA, which indicates the importance of this type of accommodation as a recruitment factor. PBSA is particularly attractive for first year undergraduate students as the influence of university provided PBSA has been found to lead to broader student outcomes as students enjoy enhanced social, cultural and extra-curricular involvement in their studies (Bliming, 1993), by means of being surrounded by similar people (age / first time away from home / studying) and the opportunity to create strong friendships. A major selling point of student accommodation is that students who stay in residence halls performed better in their studies, receiving higher average GPAs than students who did not stay in residence halls (Hountras and Brandt, 2015).

Student accommodation is attractive to students as it generates an all-in lifestyle in terms of location (accommodation being close to the university which is heralded as the most important factor in a student's choice of accommodation according to a survey of students by Knight Frank in 2019) and cost as accommodation fees typically include all bills such as gas, electricity and internet. However, the ageing stock of student accommodation owned by universities means that they need to invest in their current stock to maintain standards and to make it

\footnotetext{
${ }^{1}$ Review of post-18 Education and Funding (2019), HMSO.
} 
attractive to new students, and to be viewed as attractive as competitor PBSA provided by the private sector (Savills, 2018). The student population is no longer simply looking for lodgings which only meet basic requirements, but are looking for a higher level of service and facilities. Whilst, location and cost, together with security, continue to be fundamental in the consideration of student accommodation, the 2018/19 Knight Frank survey indicated that for at least 9 out of 10 students, fast Wi-Fi, leisure facilities such as an on-site gymnasium, the size of the room and the quality of the accommodation and it's furnishings were an important factor when deciding on where to live. The importance of competitive advantage in the university sector will be discussed further in section 2 below.

Table 1 illustrates the term time accommodation chosen by students between 2014 and 2018 . Approximately $60 \%$ of students stayed in rented accommodation, less than half of whom stayed in PBSA and the other half in other rented accommodation. In terms of PBSA, the majority of students resided in university-maintained property but there was an increase in the percentage of students staying in private sector halls between 2014 and 2018.

Table 1: Accommodation Preferences: 2014-2018

The table reports the distribution of term time student residences. Panel A presents the type of accommodation. Panel B presents a differentiation between PBSA and non-PBSA accommodation and Panel C differentiates between rented and non-rented accommodation.

\begin{tabular}{|c|c|c|c|c|}
\hline & 2014/15 & 2015/16 & 2016/17 & $2017 / 18$ \\
\hline \multicolumn{5}{|l|}{ Panel A: Type of accommodation } \\
\hline University maintained property & $19.43 \%$ & $19.31 \%$ & $19.43 \%$ & $19.32 \%$ \\
\hline Private-sector halls & $6.95 \%$ & $7.63 \%$ & $7.85 \%$ & $8.17 \%$ \\
\hline Other rented accommodation & $30.68 \%$ & $30.47 \%$ & $29.81 \%$ & $28.83 \%$ \\
\hline Parental/guardian home & $19.29 \%$ & $18.88 \%$ & $18.80 \%$ & $19.27 \%$ \\
\hline Own residence & $15.24 \%$ & $15.48 \%$ & $16.73 \%$ & $17.20 \%$ \\
\hline Other & $3.26 \%$ & $3.73 \%$ & $3.44 \%$ & $3.68 \%$ \\
\hline Not in attendance at the provider & $1.43 \%$ & $1.39 \%$ & $1.40 \%$ & $1.35 \%$ \\
\hline Not known & $3.72 \%$ & $3.12 \%$ & $2.53 \%$ & $2.19 \%$ \\
\hline Total & $100.00 \%$ & $100.00 \%$ & $100.00 \%$ & $100.00 \%$ \\
\hline \multicolumn{5}{|l|}{ Panel B: PBSA versus non PBSA } \\
\hline PBSA & $26.38 \%$ & $26.94 \%$ & $27.28 \%$ & $27.49 \%$ \\
\hline Non-PBSA & $68.47 \%$ & $68.56 \%$ & $68.78 \%$ & $68.98 \%$ \\
\hline Alternatives & $5.15 \%$ & $4.51 \%$ & $3.93 \%$ & $3.54 \%$ \\
\hline Total & $100.00 \%$ & $100.00 \%$ & $100.00 \%$ & $100.00 \%$ \\
\hline \multicolumn{5}{|c|}{ Panel C: Rented accommodation versus non-rented accommodation } \\
\hline Rented accommodation & $57.06 \%$ & $57.41 \%$ & $57.09 \%$ & $56.32 \%$ \\
\hline Non-rented accommodation & $37.79 \%$ & $38.09 \%$ & $38.97 \%$ & $40.15 \%$ \\
\hline Alternatives & $5.15 \%$ & $4.51 \%$ & $3.93 \%$ & $3.54 \%$ \\
\hline Total & $100.00 \%$ & $100.00 \%$ & $100.00 \%$ & $100.00 \%$ \\
\hline
\end{tabular}

(Source: HESA, 2018)

Cushman and Wakefield (2018) examined the PBSA market in further depth. They reported that whilst it might seem that universities provided over half $(53 \%)$ of beds, in fact the private sector supplied more than half of the beds if joint venture beds were classed as private sector beds. This trend of the private sector supplying most of the beds is set to continue. As the number of students increases and provision of private sector halls increases, the proportion of students staying in private sector halls will increase. Cushman and Wakefield (2018) found that 
in $2018 / 19,31,348$ new beds were provided by the PBSA market which was the biggest increase in new beds in one academic year. Of the 31,348 new beds, $77 \%$ or approximately 24,000 beds were provided by the private sector.

Whilst student numbers after 2022 are expected to rise across the board over the next decade, $10 \%$ of universities (a mixture of both Russell Group and post 1992 institutions who are ranked in the top 50) accounted for just over $40 \%$ of growth in student numbers highlighting that not all universities are benefitting from the removal of the sector-wide student number cap in England and Wales, while noting the difference in policy in Scotland. (Cushman and Wakefield, 2018). Indeed, reflective of students having the opportunity to 'opt up' to a higher ranked university, five low ranked universities have found that their student numbers have fallen by $25 \%$. As a result, some universities have become less attractive for PBSA investment.

From a corporate real estate perspective, the aim of this paper is to understand how the UK student residence market is structured and financed and to consider the risk and return characteristics of the differing offerings from the standpoint of the university, the private provider and the investment market. The remainder of this paper is structured as follows. Section 2 considers corporate real estate strategy and discusses the different partnership and ownership models that exist in the PBSA sector in the UK. Section 3 reviews the investment flows in PBSA, while the research design is discussed in detail in Section 4. Section 5 analyses the data and discusses the survey results and interview findings. Finally, Section 6 provides a summary and presents conclusions from the research.

\section{Literature review}

\subsection{Corporate Real Estate Strategy}

As discussed above, UK universities operate in a very competitive global market, with the sector currently facing significant financial challenges, most notable because of the prospect of a cut in undergraduate fee income combined with the uncertainty of existence in a post Brexit UK (McCann et al., 2019). For most universities, growth in revenue and profitability is very dependent on rising student numbers, both undergraduate and postgraduate. In order to grow student numbers, universities are required to offer an attractive overall 'package' - a strong academic offering, housed in a well-resourced campus with modern student residential accommodation located on campus or nearby. Given the central role of real estate in supporting this overall strategic aim of the university, it is essential that management of the university estate adopts a strategic approach. Corporate real estate (CRE) is a physical, financial and operational resource which requires close monitoring (Heywood and Kenley, 2008 and Nourse and Roulac, 1993). Universities can use their CRE to create and sustain a competitive advantage, most particularly in the context of this research, by providing better student residences in an efficient and effective manner.

Utilising a competitive advantage framework to consider the strategic management of CRE has its origins in the work of Porter (1980) and has been adopted among others by Nourse and Roulac (1993), Lindholm et al (2006), Gibler and Lindholm (2012) and Nase and Arkesteijn (2018).

Nourse and Roulac (1993) list eight alternative real estate strategies which a business can choose: 1) occupancy cost minimisation, 2) flexibility, 3) promote HR objectives, 4) promote 
marketing message, 5) promote sales and selling process, 6) facilitate and control production, operations and service delivery, 7) facilitate managerial process and knowledge work, 8) capture the real estate value creation of business. It is hypothesised that when considering provision of student residences numbers $1,2,4$ and 5 are likely to be the most directly relevant.

Lindholm et al., (2006) develop a model that translates business strategies into corporate real estate strategies making a distinction between two distinct business strategies for increasing shareholders wealth: revenue growth or profitability. Neither Nourse and Roulac (1993) nor Lindholm et al (2006) empirically test their models but this is taken up by Gibler and Lindholm (2012), who in a survey of practitioners calibrate and substantiate the model created by Lindholm et al (2006) while also making revisions by adding in environmental sustainability as a strategic aim. This revised model is shown in Figure 1 below. Interestingly, reducing real estate related costs was the most common strategy adopted by the respondents and the benefits of shorter lease terms was highlighted as an important tool to enable the organisation to adjust to the changing business strategy, a point that will be considered in more detail in section 5 .

Figure 1. Revised model of relationship of corporate real estate strategies to core business strategy.

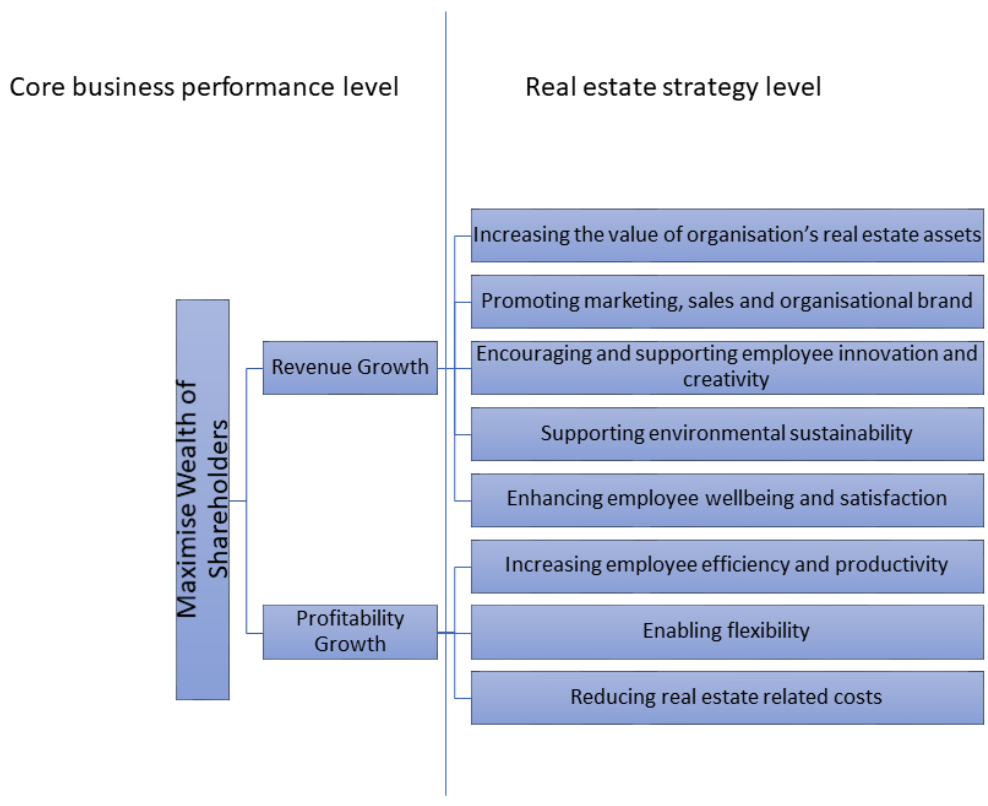

Source: Gibler and Lindholm, (2012).

In evaluating this model from a corporate real estate perspective, this research will consider whether the current strategy of UK universities in the provision of student residences is either a revenue growth strategy or a profitability growth strategy, or as appears a possibility a more student experience based approach, in which case the model will require refinement to reflect the needs of the university sector. Reducing real estate related costs and flexibility are shown as part of the strategies to support profitability growth, while promoting marketing, sales and organisational brand forms part of the strategy for revenue growth. The growth in private sector provision of student residences might well allow universities to enjoy a 'win-win', with increased revenue being combined with a reduction in costs and greater flexibility from both a physical and financial perspective. While it may seem a contradiction to believe that you can lower costs and improve services, outsourcing student residences to private sector providers 
may achieve this aim, both in the short and long term, as for example staffing costs may be cheaper for the private sector who are able to avoid public sector pensions and pay scales. That said, universities need to recognise that there are agency costs and additional risks in outsourcing, such as appropriate staffing levels of core corporate real estate staff and reputational risk of non-performance of the third-party provider (Gibler and Black, 2004).

In utilising this model as a framework to analyse university strategy, the overall objective of 'maximising the wealth of shareholders' as presented in the Gibler and Lindholm (2012) model needs to be replaced for the university sector, by a goal based around a sustainable financial objective allowing for an adequate level of reinvestment, given the predominance of charitable status in the sector. The Office for Students regulates higher education providers in England and the registration and ongoing monitoring process requires higher education institutions to demonstrate they are financially viable and sustainable. Key financial sustainability indicators comprise surplus/deficit as a percentage of total income, net operating cash flow as a percentage of total income, borrowing as a percentage of income, net liquidity in terms of number of days and total assets, and net total assets as a percentage of total income (Office for Students, 2019).

McCann et al (2019) found that since the global financial crisis in 2008, universities have been forced to look at alternative sources of finance due to the unwillingness of banks to lend for periods beyond 5 to 10 years. Given that PBSA developments are large and require long term financing, this has resulted in universities exploring different ways to provide and finance student accommodation. We explore the different models of supply of PBSA in section 2.2.

\subsection{Models of supply of PBSA}

Figure 2 illustrates the different suppliers of PBSA, ranging from university owned and operated through to university-private partnerships and direct lets from third party providers. In this section we discuss the characteristics of these in turn.

Figure 2: Suppliers of PBSA
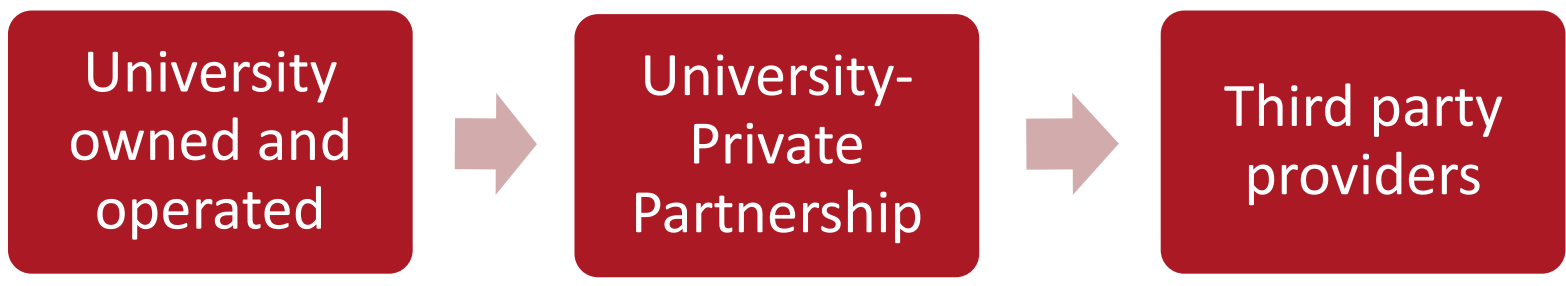

\section{University owned and operated}

Universities have historically been the major players in the PBSA market having been heavily involved in the supply and operation of student accommodation for a number of decades, particularly since the 1960s and the growth in the availability of Higher Education.

Traditionally, universities owned, operated and funded student residences (which are located on or very close to the university campus) using an on-balance sheet approach out of internally generated funds or debt finance and have viewed the supply of accommodation as a commercial let with a view to generating income. This owner-operator approach to student residences affords universities with the highest level of control over the accommodation and service that they provide. However, in a capital constrained context, university core expenditure tends to 
be focused on teaching and research and providing bed spaces is not viewed as a priority when universities have often hit their debt ceiling (Harper Planning, 2018). Consequently, over the last decade or so, some UK universities have sought to move away from this owner-operator approach and have been outsourcing the capital cost and management of PBSA to the private sector (third-party providers) or university-private partnerships.

\section{University-private partnerships}

Over the last decade, universities have added very little new stock of beds and the growth in supply of beds has come from the private sector and this pattern is expected to continue over the next few years (Cushman and Wakefield, 2018). These university-private partnerships allow universities to move the financing of student residences off-balance sheet and limit a university's long-term exposure to financial and operating risk, allowing them to focus on core educational activities.

At present, university-private partnerships are common and these can take 3 forms:

i. Design, Build, Operate and Finance (DBFO) partnerships - a university provides land and outsources the financing, building and operation of the residences, looking for a capital receipt from the residences in the future. The operating company enters into a nomination agreement with the university to rent out their rooms.

ii. Stock transfer partnerships - a university transfers part or all of its residence stock to a private company on a long-term reversionary lease.

iii. Private company takes over existing campus developments and runs them on behalf of a university.

Often in partnership form ii) and iii) the private sector refurbishes the residences.

The most popular form of university-private partnerships in the UK Higher Education sector at present are DBFOs, which are essentially consortium deals where several parties collectively work together to provide student accommodation and currently account for approximately 43,000 or $17 \%$ of all beds in the PBSA sector, with $£ 2.4 \mathrm{bn}$ having been invested in such partnerships (JLL, 2018). DBFO agreements can be on-campus developments where the university provides the land for the student residences on university owned land, or off-campus where a private company finds land which is usually located either close to a university campus or in a city centre location.

DBFO transactions are complex and there are many variations of such a deal. The basic structure of a DBFO deal built on-campus is outlined below.

1. A university leases land to a contractor who has been appointed by the university to design, build, finance and operate the student residences for a period of time. The contractor can either be a single company or a consortium of companies who have created a special purpose vehicle. In return, the university may receive a capital receipt from the contractor, if the project model generates a premium.

2. The contractor (or special purpose vehicle) will finance, build, maintain and operate the student residences, and also retain the income generated by the student residences over the lease period.

3. The university has the right, but not obligation, to enter into a nominations agreement 
with the contractor to provide a stream of student customers for the student residence. A nomination agreement is an agreement between a university and a service provider where the university agrees to fill a certain number of beds per year for a specified period of time at an agreed rental rate. Nomination agreements can range from 1 year to multiple year periods.

4. At the end of the lease period, the freehold interest in the student residence reverts back to the university.

The contractor who leases the land from the university bears the risk for the costs, design, construction, operation and maintenance of the project. The university is only liable for filling those rooms it has nominated for that year.

To ensure that DBFO projects are kept off-balance sheet via a service concession arrangement in line with accounting standard FRS 102, a university's contract with the service provider will generally be based on a soft-nomination agreement. A soft nomination agreement is a rolling one-year agreement where universities have the right, but not obligation, to nominate either an undefined or agreed number of rooms per academic year. ${ }^{2}$ The presence of a hard nomination agreement - which is a longer term agreement where universities agree to nominate an agreed number of rooms per academic year - could place the liabilities of a DBFO contract onto a university balance sheet.

\section{Private sector providers}

Private sector providers such as Unite and Campus Living Villages are further suppliers of PBSA. These companies own, invest in and develop freehold student accommodation and directly let rooms to students over the academic year. They bear the risks of construction, letting, maintenance and repair. Private sector providers typically invest in university cities, both in the city centre and close to campuses, so that they can capture demand from multiple universities in one location (Unite, 2018; Harper Planning, 2018). These companies enjoy the highest return of all types of PBSA as they have flexibility on rent price (which differs depending on demand and land prices in the location of the university), and benefit from any increase in value of the underlying property asset.

Whilst private sector providers directly let rooms to students, it is not uncommon for them to enter into nomination agreements with universities who agree to lease a certain number of beds per academic year. These nomination agreements are classified as operating leases and can last for one year or for multiple years. At present, operating leases are off-balance sheet to the university but proposed changes to FRS 102 stipulate that moving forwards, new nomination agreements that universities enter into will be on-balance sheet. ${ }^{3}$ Where the nomination agreements are for multiple years, rent price is agreed between the university and the thirdparty provider at the start of the agreement, and any future increases in rent is indexed by RPI.

\section{Alternative uses of PBSA}

Rental contracts prevalent in the PBSA market range from 38 week to 51 week per annum leases. The upshot of this is that many rooms in the sector are empty for approximately $25 \%$ of a calendar year. To prevent underuse of their assets, suppliers of PBSA attempt to lease their

\footnotetext{
${ }^{2}$ A service concession arrangement is defined as a contract between a public sector body or public benefit entity (the university) and a private operator to develop (or upgrade), operate and maintain infrastructure assets.

${ }^{3}$ Existing nomination agreements between universities and private service providers will remain off-balance sheet.
} 
rooms during the summer months to increase revenue, and in the case of university owned and operated residences the extra revenue helps to subsidise student rates.

\section{The pros and cons of outsourcing}

Brandes, Lilliecreutz and Brege (1996) suggest that there are three main reasons why a firm would choose to outsource: to focus on core competencies; cost efficiency/effectiveness and service. They suggest that there is a need for all firms to solely focus on their main business practice and specialise in that in order to create a competitive advantage over competitors. The clear benefit of outsourcing the supply of student accommodation from university owned and operated to both university-private partnerships and private sector providers is that it allows universities to free up their resources and to concentrate on their core educational activities, whilst leaving the supply of accommodation to real estate specialists (Elmuti et al (1998)). However, universities lose control over the quality of services that are provided to the students. With student satisfaction being an important component of the TEF rankings there is evidently a degree of risk inherent in the decision to outsource student accommodation. For example, in an on-campus DBFO agreement where the student accommodation is marketed as being provided by the university, the university will indirectly assume liability for the actions of the outsource service provider by means of low student satisfaction, if the quality of the accommodation is sub-standard. Moreover, universities lose the capacity to profit from student accommodation if they outsource (Moran and Taylor (1998)). The growth of outsourcing has facilitated growth in PBSA investment and this is discussed in the next section.

\section{Investment Capital Flows into PBSA}

The significant growth of investment into UK student accommodation as evidenced by a $178 \%$ increase in the value of such assets from $£ 6$ bn in 2013 to $£ 17 \mathrm{bn}$ in 2017 (IPF, 2018) is mirrored at the global level where investment into PBSA has grown each year to 2018 .

Real Capital Analytics research into global real estate investment flows indicates that over the five-year period between June 2014 and June 2019, a total of $£ 25.68$ bn was invested in purpose built student accommodation with the UK a major focus, accounting for $£ 10.21 \mathrm{bn}$ or almost $40 \%$ of the total investment. Within the UK, England captures the major share of investment (£10.10bn, 98\%) with the Greater London the principal focus (£8.56bn, 84\% of total UK investment). In contrast, Scotland (1.2\%), Northern Ireland $(0.4 \%)$ and Wales $(0.4 \%)$ received significantly lower levels of investment. Most investment since 2013 has come from overseas, primarily from the US (£3bn) and from Asia (£2.2bn) (Savills, 2019b).

Investor demand for PBSA at global and local level, together with quantitative easing and low interest rates have driven the transformation from a niche to a distinct mainstream asset class characterised by a wave of investment into new building in the UK resulting in a hardening of yields at 5.5\% and a narrowing spread to gilts at 4.0\% (Savills UK, 2018). Newell and Marzuki (2018) identify key global investors in PBSA as GIC, CPPIB, APG, Bouwinvest, PGGM and Temasek. These investors often invest in student accommodation across several countries. The principal investors in the UK PBSA market are Wellcome Trust, IQ Student Accommodation, Empiric Student Property, GCP Student Living, all of which are based in London, and Unite Students REIT located in Bristol (Real Capital Analytics). In addition, many property fund managers are actively investing in student accommodation in both listed and non-listed vehicle structures. For example, Principal, Mapletree, Aberdeen and Hines, as well as US and UK student accommodation REITs have been established. In this regard, they identified over 35 major players with student accommodation in their funds. 
The increased investment into PBSA has been facilitated by the emergence of highly professional operators of student accommodation with sophisticated operating platforms in recent years to supplement property fund manager and institutional investor activity. These include UNITE, Liberty Living, CRM students, Fresh Student Living, Housing for Students, Campus Living Villages, Sanctuary Student Housing, UPP, 360 Developments and Vero Living (Newell and Marzuki, 2018).

The dramatic growth in the student residential sector has raised the spectre of oversupply following a building boom across a number of UK cities. The rapid explosion in student numbers has been followed by a frenzy of construction activity resulting in an educationthemed real estate sector providing accommodation for circa 600,000 people, equivalent to one third of the student population and currently estimated to be worth $£ 50 \mathrm{bn}$. Some investors have expressed concern that university towns are now overbuilt and that such investment is distorting local economies and housing allocation when there is a significant need for social and family homes. (Financial Times, 2019).

The risk of oversupply producing a decline in investor demand is evidenced by the investment trend which in the UK showed a lending high in 2015 and has been declining since, with the 2017 figure of $£ 3.1$ bn being $45 \%$ less than the peak (Savills, 2018). While there is a long-term rising trend of global student residence investment since 2007 (Knight Frank, 2018), local markets such as the UK may be showing early signs of the first identifiable cycle in PBSA. Without a longer-time series of PBSA investment data it is not possible to confirm if this asset class will follow prime market cyclical patterns (Goodchild, 2017).

Currently, a wider range of risks are influencing investor appetites in the UK including political uncertainty, Brexit, immigration and demographic factors. Brexit and possible changes to immigration in particular are producing an uncertain future for international students especially regarding future fee levels. With many UK universities specifically promoting PBSA for international applicants, uncertainty mounts regarding future student housing cash flows. Demographic factors relate to the decline in UK student age population which from 2022 is expected to return to growth in particular for those locations which are best able to offer flexible accommodation and amenities that future generations of students may require (Savills, 2018).

\subsection{Research Methods}

\section{Design}

To examine the factors that affect the provision of student accommodation, we surveyed university secretaries in the summer of 2019. We also conducted a number of informal meetings with our home university secretaries and directors of estates. As the private sector is also heavily involved in the provision of student accommodation, we conducted interviews with four active private sector providers.

We supplemented our survey approach by interviewing three other parties in the spring and summer of 2019. First, we interviewed two major banks which have considerable experience in lending to the Higher Education sector. Second, we interviewed an independent corporate finance adviser who specialises on the Higher Education sector and third we interviewed a student communication specialist who has advised universities (and leading providers of private sector student accommodation) on student preferences regarding student accommodation. We discuss each approach in turn. 


\section{University surveys}

Our survey focused on how universities provide student accommodation and the issues of supply and demand surrounding the provision of such accommodation both in the past and looking towards the future. We surveyed university secretaries from all UK universities during the autumn of 2019., ${ }^{4,5}$ We used two methods to deliver the survey. First, we posted a hard copy of the survey to each university secretary. We requested that the surveys be returned to us within 3 weeks using a provided stamped addressed envelope. To encourage responses after this 3 week period ended, we then sent an online version of the survey to each university secretary by email asking them to respond within 2 weeks. We received 66 survey responses in total, representing $41.77 \%$ of the population. ${ }^{6,7}$

\section{Private sector provider interviews}

As the percentage of students staying in private sector halls continues to increase, it is important to understand the issues surrounding the supply of student accommodation from the perspective of such providers. Therefore, during 2019, we conducted face to face and telephone interviews with four major providers of private sector student accommodation: Unite, Student Roost, GSA and Sanctuary Housing.

\section{Bank/Debt Finance Providers}

To gauge the current appetite for lending to providers and developers of student residences, interviews were conducted with two major UK banks. A telephone interview was held with Barclay's Bank involving senior staff in university, education and real estate lending. In addition, a written response to interview questions was received from Bank of Ireland corporate and real estate lending. Both responses addressed current issues of lending into the sector, management of risks and perceptions of future prospects.

\subsection{Analysis of results}

\section{(i) Survey of UK universities}

In total 66 survey responses were returned, representing $41.77 \%$ of the population, which compares very favourably to the response rate of $16 \%$ that McCann et al (2019) obtained in a recent survey of Finance Directors from all UK universities during the summer of 2018. Of the responses, $16.67 \%$ of responses were in hard copy format and $83.33 \%$ in an online format. More than three quarters of the respondents (51) were universities based in England, 12 respondents were universities based in Scotland, 2 from Northern Ireland and 1 from Wales. 12 (18.18\%) respondents were Russell Group universities, and 38 (57.58\%) respondents were post-92 universities indicating a mix of responses from different groups of universities. Of the 66 respondents, 4 universities were not involved either directly or indirectly with the supply of student accommodation and did not proceed with the survey. Our survey results are presented in Tables 2 to 5, and in Figure 3.

\footnotetext{
${ }^{4}$ To ensure our survey was apposite, we conducted a pilot study amongst the authors' home universities and edited it as required prior to sending it out to universities.

${ }^{5}$ Whilst the survey was sent to university secretaries, in many cases the survey was passed onto directors of estates, heads of accommodation services and other equivalents to fill in on their behalf.

${ }^{6}$ Of the 66 responses, we received 11 hard copy responses (16.67\%) and 55 online responses (83.33\%).

7 Sending an online version of the survey to university secretaries was planned in advance and designed to maximise the response rate.
} 
Respondents were questioned on the main motivations for being involved in the market for student residences. The fundamental motivation was that universities recognise the key role that student accommodation plays as a core function of a university in the overall student experience in terms of student welfare and wellbeing, but also importantly in student recruitment and student retention. Unsurprisingly, income generation was also a key motivation with a number of respondents noting that the provision of student residences was used to deliver a surplus back to the university to allow it to invest in the upkeep of existing, and provision of new, strategic initiatives, services and facilities on campus for the students. Indeed, two-thirds of universities lease their student beds during non-term time. Moreover, several respondents indicated that they were involved in the student residence market as a result of the location of their university. For example, for universities based in rural locations, satisfying demand due to a lack of locally available housing was a key factor for providing student accommodation, as was the provision of affordable accommodation in areas with high private rental prices.

For those involved in the provision of student residences, $74 \%$ of universities owned and operated their own residences, $26 \%$ were involved in DBFO contracts, $48 \%$ entered into nomination agreements with third party providers, and $32 \%$ had left the provision of student accommodation to the private sector (with only minor, e.g. referral, involvement with the university).

Table 2 - Provision and financing of student residences

The table reports summary statistics on the provision and financing of student residences in the UK university sector. Panel A examines how universities currently provide and finance student residences. Panel B examines how universities are likely to provide and finance student residences over the next 5 years.

Panel A: How does your university currently provide and finance student residences?

Proportion of respondents

University owned and operated residence

$74.24 \%$

University fund construction of residence and then lease to a third party who operates

University grants head lease to SPV - who designs, builds, finances and operates

residence for a typical period of $\mathrm{c} 40$ years

Third party provide residence and the university enters into nomination agreements

$48.48 \%$

Third party directly lets student beds to the market with only minor (referral or equivalent) or no involvement with the university

Panel B: How is your university likely to provide and finance future student residences over the next 5 years?

\begin{tabular}{|c|c|}
\hline University owned and operated residence & $50.00 \%$ \\
\hline University fund construction of residence and lease to a third party who operates & $6.06 \%$ \\
\hline $\begin{array}{l}\text { University grants head lease to SPV - who designs, builds finances and operates } \\
\text { residence for a typical period of c } 40 \text { years }\end{array}$ & $28.79 \%$ \\
\hline $\begin{array}{l}\text { Third party provide residence and the university enters into a nomination } \\
\text { agreement }\end{array}$ & $40.91 \%$ \\
\hline $\begin{array}{l}\text { Third party directly lets student beds to the market with only minor (referral or } \\
\text { equivalent) or no involvement with the university }\end{array}$ & $28.79 \%$ \\
\hline No plans to grow the supply of student residences at present & $24.24 \%$ \\
\hline
\end{tabular}

Respondents were asked what the perceived risks and benefits of the university owning and operating their own student residences and/or outsourcing the provision to a third party. Table 3 outlines the pros and cons of each supply model of PBSA from the university perspective. 
Table 3 - Pros and cons of supply models of student residence

The table reports a summary of the pros and cons of each supply model of student residence as outlined by our survey respondents.

\begin{tabular}{|c|c|c|c|}
\hline & University owned and operated & University private-partnership & Third-Party provider \\
\hline Pros & $\begin{array}{l}\text { Control of assets } \\
\text { Reliable source of significant rental income } \\
\text { Control of student experience } \\
\text { Control over rental prices }\end{array}$ & $\begin{array}{l}\text { Preserves balance sheet for core activities } \\
\text { Generates a capital receipt } \\
\text { Reduced cost risk }\end{array}$ & $\begin{array}{l}\text { Preserves balance sheet for core activities } \\
\text { No cost risk to university } \\
\text { Newer accommodation provision }\end{array}$ \\
\hline Cons & $\begin{array}{l}\text { Borrowing is on-balance sheet } \\
\text { Full cost risk } \\
\text { Diverts funding from teaching and research } \\
\text { Asset and operational management }\end{array}$ & $\begin{array}{l}\text { Complicated agreements } \\
\text { Procurement can be difficult } \\
\text { Reduced control of student experience } \\
\text { Reduced control over rental prices } \\
\text { Lack of regular rental income }\end{array}$ & $\begin{array}{l}\text { No regular rental income or future capital receipt } \\
\text { No control of student experience } \\
\text { No control over rental prices }\end{array}$ \\
\hline
\end{tabular}

Source: QMPF as amended by authors using survey responses.

On average (median), university owned and occupied residences offered 2,151 $(1,725)$ student beds, with an average occupancy rate of $93.66 \%$ and an average lease length of 42 weeks, but the number of beds offered by universities ranged from 60 to 7,000, representing differences in the size of universities (student numbers) and also the location of the universities. The average (median) student beds offered by means of all other contracted provision including a range of partnerships with third parties was 1,532 (735) beds.

Table 4 - Bed spaces

This table presents descriptive statistics on the number of and occupancy of bed spaces in the UK university sector. Panel A examines how many student beds that universities are currently involved with. Panel B examines the average occupancy rate of university owned and operated residences. Panel C examines how many student beds universities plan to be involved with over the next 5 years.

\begin{tabular}{|c|c|c|c|c|}
\hline & Mean & Median & Min & Max \\
\hline \multicolumn{5}{|l|}{$\begin{array}{l}\text { Panel A: How many student beds is your university currently involved } \\
\text { with? }\end{array}$} \\
\hline $\begin{array}{l}\text { University owned and operated residencies: } \\
\text { All other contracted provision including range of partnerships with third } \\
\text { parties: }\end{array}$ & 1532 & 1725 & 60 & 7020 \\
\hline $\begin{array}{l}\text { Panel B: What is the average occupancy rate in university owned and } \\
\text { operated residencies? }\end{array}$ & $93.66 \%$ & $96.5 \%$ & $60 \%$ & $100 \%$ \\
\hline \multicolumn{5}{|l|}{$\begin{array}{l}\text { Panel C: How many new bed spaces do you plan to provide or be } \\
\text { involved with over the next } 5 \text { years? }\end{array}$} \\
\hline $\begin{array}{l}\text { University owned and operated residencies: } \\
\text { All other contracted provision including range of partnerships with third } \\
\text { parties: }\end{array}$ & 516 & 300 & & 3084 \\
\hline
\end{tabular}

The nomination agreements that universities have entered into range from an academic year (min 38 weeks) to 50 years. $62 \%$ of universities have nominations agreements with a tenure of one year or less, whilst 54\% have nomination agreements with a longer term tenure. Universities appreciate the flexibility of short nomination agreements because of uncertainty over demand levels from year to year, and the need to prioritise occupancy of university-owned and operated residences for income generation purposes. Universities which have longer term nomination agreements have such arrangements for a number of different reasons. Some universities view a medium term nomination agreement as the correct balance for medium term planning purposes, allowing them to balance certainty with flexibility, and one university opted 
for a longer term nomination agreement because of an undersupply of PBSA in their university city. Others however, have longer term nomination agreements as a result of historical decision making.

Respondents were asked about the type of accommodation that they offer. $78 \%$ of respondents offered en-suite facilities and those who currently did not offer such facilities indicated that any new university owned and operated bed spaces would include an en-suite bathroom because this type of accommodation lets quickest. $70 \%$ of universities continued to offer shared facilities (single bedroom, shared living space) but such accommodation was the hardest to let and normally any un-let stock was shared accommodation where the university offered en-suite accommodation. $42 \%$ of universities provided studio apartments. One university noted that they offered twin rooms.

Table 5 - Type of accommodation

This table presents summary statistics of the type of accommodation provided by UK universities. Panel A examines the type of accommodation that universities offer. Panel B examines which type of accommodation lets quickest.

\begin{tabular}{lc}
\hline Panel A: In university owned and operated residences what type of & \\
accommodation does your university provide? & Proportion of respondents \\
\hline En-suite & $78.79 \%$ \\
Studio & $42.42 \%$ \\
Shared & $69.70 \%$ \\
\hline Panel B: What type of accommodation lets quickest? & $81.48 \%$ \\
\hline En-suite & $12.96 \%$ \\
Studio & $5.56 \%$ \\
Shared & \\
\hline
\end{tabular}

The second part of the survey asked respondents about their university's future plans vis-à-vis the provision of student residences. 50\% of universities indicated that they would provide and finance future residences on a university owned and operated basis, However, reflecting a move from owner operated residences to private sector provision, the average amount of new bed spaces that universities planned to provide themselves within the next 5 years (516) was almost half of what they had planned to be provide in association with the private sector (906) over the same time period. $29 \%$ of universities would pursue a DBFO arrangement, $41 \%$ would seek to enter into new nomination agreements with private sector providers, and $29 \%$ had decided to leave the provision of student residences entirely to the private sector. One-quarter of universities had no plans to grow the supply of student residences either on an owner operated basis or in involvement with a private sector provider at present. Respondents were asked if sector changes had impacted their forward-looking student residence policies. The majority of English universities noted that the removal of the student cap in numbers had driven an increase in demand for student residences, but the majority of respondents stated that the introduction of TEF had not impacted their residence policy.

In the final part of the survey we questioned the universities on the key drivers behind their real estate strategy towards university owned student residences. From these outcomes we were able to develop a new version of the Gibler and Lindholm (2012) model of the relationship of corporate real estate strategies to core business strategy, which reflects the current strategy of UK universities in the provision of student residences, and the most prominent Higher Education sector risks over the last 5 years as outlined by PwC (2019). This new version of the 
model is shown in Figure 3.

Enhancing student wellbeing and satisfaction/improved student experience was the most common strategy adopted by the respondents (79\%), but income/revenue growth strategies were also important. Therefore, we are able to make a distinction between two distinct strategies for increasing the financial sustainability of universities: income/revenue growth and student experience improvement. These strategies reflect the dual role of student residences as an income generator and as a central part of the student experience and guardian of student wellbeing. PwC (2019) state that financial sustainability (including pensions) and student recruitment (linked to student experience) are in the top three Higher Education sector risks for the years 2015 to 2019 .

Applying these strategies for increasing the financial sustainability of universities to corporate real estate strategies, we adapted the Gibler and Lindholm (2012) model to reflect the university sector. 59\% percent of respondents had used their student accommodation as a means of reducing real estate related costs and as a strategy to increase the value of the university's real estate assets. Moreover, 39\% of respondents used their student accommodation as a means of promoting marketing, sales and organisational brand. The benefits of flexibility in providing residences to students was also highlighted as an important tool to enable the university to adjust to the changing demands and strategies.

Figure 3 - Revised model of relationship of corporate real estate strategies to core university strategies in the UK.

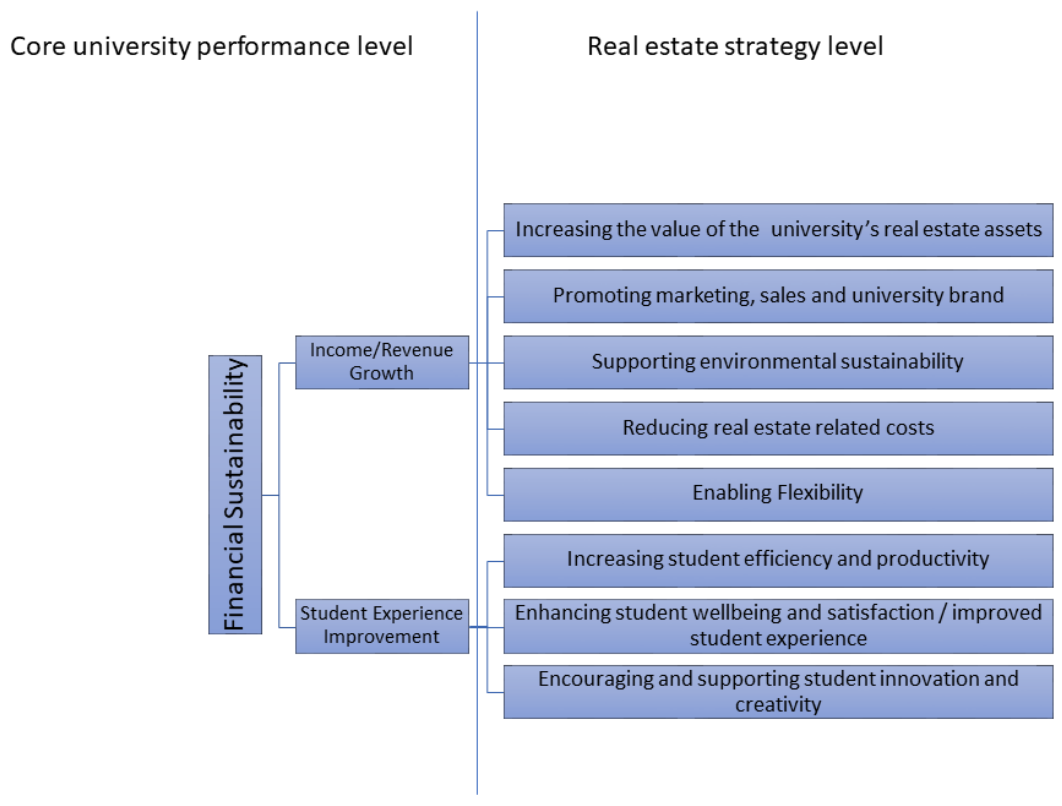

(ii) Interviews with private sector providers

Four private sector providers of student accommodation were interviewed in mid-2019. In total those interviewed currently offer 93,000 student beds out of the approximately 320,000 private sector beds available in the UK. One of the providers also operated student beds overseas with significant differences noted in the type of space required. For three of out of the four providers, their focus was solely on the student let market while for the other provider, social housing was the main focus, with student beds being a secondary activity. 
Four key themes emerged from our semi structured interviews with the providers of student accommodation: portfolio of and location of residences; nomination agreements with universities; lease length and type of student accommodation.

\section{Portfolio of and location of residences}

For each of the providers, growth in their student residence portfolio had occurred through both new development and acquisition, with the last two years witnessing the sale of existing stock to new operators. Interestingly, there was a polarised view on future growth prospects with two of the providers anticipating strong growth, one moderate growth while the other believed that the market for student accommodation was saturated in many cities in the UK and they had no plans to expand their portfolio. All of the providers use UCAS application data as their key indicator of demand, carefully noting shifts in the popularity of universities and courses. Results in the TEF as well as the university's own strategy documents and financial statements are also included in the decision matrix to build new bed spaces, acquire existing stock or disinvest.

For those that had grown their portfolio through acquisition, the choice of city or specific location of the residence was not of their own making. However, those involved in developing new space, implemented a bespoke strategy for each city, with proximity to the university high on the agenda. None of those interviewed adopted a Russell group only city strategy, although comment was made that operating within a Russell group city did reduce void risk which is consistent with the growth rate of students in Russell group universities (20.2\%) being substantially greater than that of non-Russell group universities (9.4\%) between 2012/13 and 2017/18 (HESA, 2019). That said, recent years have seen some non-Russell group universities achieve higher growth rates than Russell group universities within individual cities. For example, in the city of Manchester, the University of Salford achieved a student growth rate of $10.2 \%$ between 2012/13 and 2017/18, but in comparison the growth rate of students in the University of Manchester was only 8.9\% (HESA, 2019).

Locating in a city with multiple universities and possibly a further education college was seen as particularly attractive due to high levels of demand and reduced operating costs per bed. There was consensus that there was over-provision of bed spaces in certain locations which reduced rental levels and increased the number of voids. This was caused by over development of new space rather than necessarily poor performance of the university. This had resulted in one provider, disinvesting from certain cities in 2018 and reinvesting elsewhere, in order to move up the quality ladder.

Another important factor is the underlying real estate value of the cities that universities are located. For example, should the demand for student accommodation in Brighton drop, the underlying property value in Brighton is high, making it an attractive city for PBSA investment and development as investors are confident that their investment can be re-purposed into flats.

\section{Nomination agreements with universities}

All of the providers entered into nomination agreements with the universities, with two of the providers having approximately $60 \%$ of their stock held under agreements, while the other two have less than $20 \%$. The length of the nomination agreements were predominantly for one or two years, although the range was from 1 to 25 years, with the length of the agreements depending on the needs of the university and their strategy for their own stock. The longer nomination agreements occur with universities both north and south of the border and not just 
in London where residential space is at a premium. Some of the nomination agreements have void risk clauses, where the university covers any shortfall in occupancy, otherwise the provider must try and fill any voids.

\section{Lease length}

Length of the letting contracts range from 44 to 51 weeks, depending on the location. For some providers it is possible to let the beds in the summer months thus increasing the cash flow. Examples including letting beds to visitors to London and to Edinburgh at the time of the festival. Rental levels are variable between the cities reflecting supply and demand of the student beds and the wider health of the local housing market and the availability and cost of space in the houses in multiple occupancy (HMO) market.

\section{Type of accommodation}

The view was that the expectations of students is much higher than ever before, but whilst ensuite accommodation tended to let the quickest, there was a need to offer a range of options, including different configurations of space, size and levels of affordability. It was commented that where a university had strong demand from international students there tended to be differential levels of willingness to pay for accommodation, with the Chinese students being more affluent than those from Africa and India and thus willing to pay more.

\section{Other factors}

The standard of university provided accommodation was generally perceived to be lower than that provided by the private sector and generally regarded as not as good value for money. But despite this, university provided accommodation continues to be popular, particularly for first year students because of the benefits of the "wrap around care" and "on campus support" that university provided residences can provide.

(iii) Interviews with bank lenders

Two active bank lenders to the student accommodation sector were interviewed in mid-2019. Both banks agreed that student accommodation is currently viewed as an attractive sector, and that the sector is likely to continue to provide plenty of opportunity in the long term. From a lending perspective, it offers exposure to a liquid market, attractive to a wide range of domestic and international investors, meaning value volatility is currently low. Moreover, for welllocated and managed schemes, student accommodation has the capacity to generate a stable income profile on which debt repayment can be based. Four key themes emerged from our interviews with the bank lenders: risk; university credit rating; nomination agreements; and loan to value and debt yield.

Risk

Four major risks involved in lending to this sector are identified.

(i) Market risk: Recent years have seen a number of opportunities to develop new schemes in cities where traditionally the student accommodation asset class did not exist or was limited, but where currently there is significant university growth. However, such cities too will have a natural limit and in locations approaching capacity, lenders will limit their appetite to the best located schemes, operated by established industry players. In the past one bank considered lending in Russell 
university cities only, but this is no longer the case. However, there are clearly locations where banks would not lend due to either oversupply in the market or where universities in those town or cities are struggling to reach their student numbers.

(ii) Operational risk: Lenders are focused on whether the projected rental levels will be achievable in the market and will assess the experience of the operator in the area of the proposed student accommodation and whether their revenue / cost assumptions are consistent with comparable schemes.

(iii) Repayment risk: Lenders need to consider whether the project can generate sufficient net operating income to repay the debt and whether it is sufficient to repay the debt in full over an agreed maximum term. A key issue that lenders are concerned about is occupancy levels. Therefore, projected student lease lengths are very important to a lender as cash flows are based on what the standard lease length would be expected to be. In cities such as Edinburgh, lease lengths would be expected to be 51 weeks because of the festival, but other towns with no summer business would normally be evaluated on a 44 week let.

(iv) Construction/development risk: One lender indicated that construction and development risk has become increasingly important. Lenders are increasingly concerned about the developer's track record and ability in delivering student accommodation projects to the required specification and within budget.

(v) Brexit risk: Lenders have acknowledged the potential impact of Brexit on UK student numbers when making lending decisions, specifically the level of international students who will be coming to the UK to study given a large proportion of these students are potential users of student accommodation which may reduce demand.

\section{University credit rating}

One of the largest changes in lending practice in the higher education sector at present relates to credit rating. Formerly, the difference between the very best university credit rating (for example Oxford or Cambridge) and the very worst credit rating (for example a fairly new university operating in a widening participation scheme or civic agenda) was negligible on overall lending practice. Now the credit difference between the two is substantial, but it doesn't mean that the actual credit profile in the sector has worsened - indeed, at the top end it is probably better as the shackles have been taken off to allow the best universities to grow home and international student numbers.

\section{Nomination agreements}

Lenders indicate that the type of nomination agreement secured by providers of student accommodation has an impact on how they fund developments. Hard nominations agreements in the region of five years in length, help to reassure lenders as the guaranteed student rent receivable enables the lender to repay the loan. Shorter term nomination agreements in the first year of new student residence, also helps facilitate lending. Longer term lease partnerships between a university and a third party provider tend to be funded more from the bond market rather than from banks due to the tenure of these agreements. 


\section{Loan to value and Debt Yield}

Many factors are considered when assessing appropriate Loan to Value and Debt Yield. These include demand/supply, location, experience/track record and the balance sheet strength of the provider. Lenders will generally be more cautious with a single asset scheme than larger portfolios. Debt funds and alternative lenders will typically have more aggressive criteria, albeit at a cost to the borrower.

\subsection{Conclusions}

Dramatic changes in UK higher education are reflected in increased undergraduate entrants. The increased number of students stems from the removal of the cap on student numbers, an increasing participation rate, favourable demographics, a growth in overseas students attracted by the reputation of UK universities, the weakening of the value of Sterling and increasing competition among UK universities seeking to expand their income as public sector funding has declined.

The role of PBSA designed to meet modern student requirements is playing a critical role not only in attracting, recruiting and retaining students but also enhancing the overall higher education experience promoting student welfare and wellbeing.

At a time when university finances are under pressure, the private sector is increasingly filling the gap in the provision of modern residential facilities in contrast to University stock which often tends to be old, expensive, and difficult to update. However, the stellar growth of development in this real estate sector is producing its own challenges with claims that the market is saturated in some UK university locations. This has resulted in some private sector operators repositioning their portfolios and more scrutiny by providers and their lenders on occupancy levels and cash flow projections. However, if the HEPI (2018) prediction of 300,000 more students by 2030 is correct, there is considerable need for further investment in student accommodation to house the forecast number of students.

The findings of the survey clearly demonstrate that universities are prioritising student experience and wellbeing with modern purpose built student accommodation a key element in this approach to attracting student numbers thereby driving income and revenue growth strategies. In the main their real estate strategy is one of outsourcing student accommodation, which helps to preserve scarce capital for more direct educational activity, while at the same time reducing costs and being able to employ modern purpose built student housing as a marketing/recruitment tool and brand enhancer. This strategy is also used as a risk mitigatory enabling universities to adjust to changing student demands, through the judicious use of nomination agreements, which for both parties need to balance a degree of certainty with flexibility. Best practice would suggest that it is also important that in any partnership arrangement, the wellbeing of the students is front and centre and that the provision of such a service is seamless and of a high standard whoever actually owns the real estate and operates the residence. The partnership of universities and private sector providers is likely to be the dominant tool used by universities to ensure the adequate supply of student residences for the foreseeable future. 
The research indicates that the classic corporate real estate model of maximising profitability is not suitable for the current university real estate strategy which seeks to increase the value of university assets through enhancing student experience thereby generating income to further improve wellbeing. The new revised Gibler-Lindhom model allows us to review the university sector in a new systematic way.

Acknowledgements

The authors would like to thank the large number of participants in this research for their contribution. Among others these include university secretaries and estate directors, QMPF, Real Capital Analytics, Barclays, Bank of Ireland, Unite, Student Roost, GSA, Sanctuary Housing and Campus Life.

References

Augar, P. (2018), "Review of Post-18 Education and Funding," Available at https://assets.publishing.service.gov.uk/government/uploads/system/uploads/attachment_data /file/805127/Review_of_post_18_education_and_funding.pdf

Blimling, G. S. (1993). "The influence of college residence halls on students". In J. Smart (Ed.), Higher education: Handbook of theory and research. Volume 9, pp. 248-307. New York: Agathon

Brandes, H., Lilliecreutz, J. and Brege, S. (1997), “Outsourcing-success or failure?”, European Journal of Purchasing and Supply Management, Vol. 3, No. 2, pp.63-75.

Cushman and Wakefield (2018). "UK Student Accommodation Report 2018”, Available at: http://www.cushmanwakefield.co.uk/en-gb/research-and-insight/2018/uk-studentaccommodation-report-2018

Elmuti, D., Kathawala, Y. and Maonippallil, M. (1998), "Outsourcing to gain a competitive advantage”, Industrial Management, Vol.40, No, 3, pp.20-24.

Financial Times. (2019), “Higher education: is Britain's student housing bubble set to burst?”, Financial Times, accessed on: 16 September 2019.

Gibler, K.M. and Lindholm, A. (2012), “A test of corporate real estate strategies and operating decisions in support of core business strategies”, Journal of Property Research, Vol. 29, No. 1, pp.25-48.

Gibler, K.M. and Black, R.T. (2004), "Agency risks in outsourcing corporate real estate functions”, Journal of Real Estate Research, Vol. 26, No. 2, pp.137-160.

Goodchild, R. (2017), "Nature of Property Cycles: Past, Present and Future”, LaSalle Investment Management, Available at: https://www.culandsoc.com/wpcontent/uploads/2017/05/20170509-Nature-of-Property-Cycles-IPF_SPR_CULS.pdf

Gregory, N. (2016), "How does 'place making add to the university experience?”. Available at: https://universitybusiness.co.uk 
HEPI. (2018), "Demand for Higher Education to 2030 Report". Available at: https://www.hepi.ac.uk/wp-content/uploads/2018/03/HEPI-Demand-for-Higher-Educationto-2030-Report-105-FINAL.pdf

HESA. (2018), "Higher education student statisitics", Available at: https://www.hesa.ac.uk/news/17-01-2019/sb252-higher-education-student-statistics

Heywood, C. and Kenley, R. (2008), "The sustainable competitive advantage model for corporate real estate,” Journal of Corporate Real Estate, Vol. 10, No. 2, pp.85-109.,

Hountras, P.T and Brandt, K.R. (2015), "Relation of Student Residence to Academic Performance in College”, Journal of Educational Research, Vol 63. No. 8, pp. 351-354

IPF. (2018) The Size and Structure of the UK Property Market, Investment Property Forum. Available at: https://www.ipf.org.uk/resourceLibrary/the-size---structure-of-the-uk-propertymarket---year-end-2017-update.html.

JLL. (2018), "Co-living - the graduation from Student Housing”. Available at: https://capitalmarkets.jll.com/report/co-living-graduation-student-housing/

Knight Frank. (2019), "Student Accommodation Survey 2018/19," Available at: https://www.knightfrank.co.uk/research/knight-frank-ucas-student-housing-survey-2018196002.aspx

Knight Frank. (2019), "Global Student Property Report," Available at https://content.knightfrank.com/research/1775/documents/en/global-student-property-report2019-may-2019-6426.pdf

Lindholm, A-L, Gibler, K. M. and Leväinen K. I. (2006), "Modelling the valueadding attributes of real estate to the wealth maximization of the firm, " Journal of Real Estat e Research, Vol. 28, Issue 4, pp. 445-75.

McCann, L, Hutchison, N.E., and Adair, A.s. (2019), "External funding of major capital projects in the UK Higher Education sector: issues of demand, supply and market timing?" Journal of Property Research, Vol. 36, No. 1, pp. 97-130.

Moran, M. and Taylor, J. (1998), “Outsourcing: Managing risk”. Executive briefs, April 1-4, Cambridge MA: International Society of Facilities Executives

Nase, I. and Arkesteijn, M. (2018), "Corporate real estate strategies and organizational culture”. Journal of Corporate Real Estate, Vol. 20, No. 3, pp154-176.

Newell, G. and Marzuki, J.M. (2018), "The emergence of student accommodation as an institutionalised property sector, " Journal of Property Investment and Finance, Vol 36, No 6, pp 523-538

Nourse, H. and Roulac, S.E. (1993), "Linking real estate decisions to corporate strategy," Journal of Real Estate Research, Vol. 8, No. 4, pp. 475-494.

Nyren, R. (2019), “Student Housing,” Urban Land, Vol 78, No. 4, pp. 90-94. 
NUS, (2018). “Accommodation Costs Survey", Available at:

https://www.nusconnect.org.uk/resources/nus-and-unipol-accommodation-cost-survey-2018full-report

Office for Students. (2019), "Financial sustainability of higher education providers in England," Available at: https://www.officeforstudents.org.uk/publications/financialsustainability-of-higher-education-providers-in-england/

PwC. (2019), "Managing Risk in Higher Education: Higher Education Sector Risk profile 2019”. Available at: https://www.pwc.co.uk/government-public-

sector/education/documents/higher-education-sector-risk-profile-2019.pdf

Savills. (2019), “The Sky's the Limit, UK Operational Real Estate”. Available at: https://www.savills.co.uk/research_articles/229130/283702-0

Savills World Research. (2018), "Global Living: Student, Senior Housing \& Multifamily Occupier Demands”. Available at: https://pdf.euro.savills.co.uk/global-research/spotlight--global-living-2018.pdf

Savills. (2018), "World Student Housing", Available at: https://www.savills.co.uk/research_articles/229130/220689-0

Savills. (2018), "Student accommodation", Available at: https://www.savills.co.uk/research_articles/229130/283706-0

Savills. (2018), "Challenges for student housing investment", Available at: https://www.savills.co.uk/research_articles/229130/267737-0 